\title{
TANGGUNG JAWAB PENERIMA HIBAH DALAM PERJANJIAN HIBAH DAERAH BERDASARKAN PERATURAN BUPATI BADUNG NOMOR 43 TAHUN 2018
}

\author{
I Made Ary Diantara, Program Studi Magister Ilmu Hukum, Fakultas Hukum \\ Universitas Udayana, E-mail: ary.diantara@gmail.com \\ I Ketut Sudantra, Fakultas Hukum Universitas Udayana, \\ E-mail: sudantra01@yahoo.co.id
}

doi: $\underline{\text { https://doi.org/10.24843/KS.2020.v09.i01.p06 }}$

\begin{abstract}
ABSTRAK
Bantuan berupa hibah diberikan oleh pemerintah daerah kepada pemerintah atau pemerintah daerah lainnya, badan-badan usaha yang dimiliki oleh daerah, kelompok usaha yang ada pada masyarakat serta organisasi dalam masyarakat untuk melaksanakan pembangunan yang merata agar terciptanya pembangunan yang berkembang dan berkelanjutan. Tanggung jawab penerima hibah dalam penggunaan dana hibah yang tidak sesuai dan berbeda dengan usulan penggunaan dana hibah dan sanksi yang dapat diterima penerima hibah apabila tidak sesuai dengan usulan hibah menjadi permasalahan dalam artikel ini. Tujuan penulisan ini untuk mengkaji tanggung jawab penerima hibah serta sanksi apabila tidak sesuai dengan penggunaan dana hibah. Penulisan jurnal ini menggunakan metode penelitian normatif serta menggunakan pendekatan perundang-undangan. Hasil dari studi ini adalah bahwa dalam Peraturan Bupati Badung Nomor 43 Tahun 2018, dalam laporan pertanggungjawaban dana hibah kepada SKPD/unit kerja terkait, maka masyarakat harus bertanggung jawab secara penuh atas dana yang digunakan. Apabila dana yang tidak sesuai digunakan dalam Naskah Perjanjian Hibah Daerah, maka penerima hibah harus mengembalikan secara penuh dana tersebut kepada pemerintah. Sanksi yang dapat dikenakan penerima hibah apabila menyalahgunakan dana hibah dapat berupa sanksi administratif berupa pengembalian dana secara penuh kepada pemerintah daerah dan sanksi pidana apabila penerima hibah menggelapkan dana hibah.
\end{abstract}

Kata Kunci: Hibah, Tanggung Jawab, Sanksi

\begin{abstract}
Assistance in the form of grants is given by the local government to the government or other local governments, business entities owned by the region, existing business groups in the community and organizations in the community to carry out equitable development in order to create a development that is sustainable and sustainable. Responsibilities of grant recipients in the use of grant funds that are not appropriate and different from the proposed use of grant funds and sanctions that can be accepted by grantees if they are not in accordance with the proposed grant are the issues in this article. The purpose of this paper is to examine the responsibilities of grantees and sanctions if they are not suitable for the use of grant funds. The writing of this journal uses normative research methods and uses a statutory approach. The result of this study is that in Badung Regent Regulation No. 43 of 2018, in the accountability report of grants to SKPD / related work units, the community must be fully responsible for the funds used. If funds that are not suitable are used in the Regional Grant Agreement text, the grant recipient must return the funds in full to the government. Sanctions that can be imposed by the recipient of the grant if the misuse of the grant funds can be in the form of administrative sanctions in the form of a full refund to the local government and criminal sanctions if the recipient of the grant embezzled grant funds.
\end{abstract}

Keywords: Grants, Responsibilities, Sanctions 


\section{Pendahuluan}

\subsection{Latar Belakang Masalah}

Pemerintah merupakan salah satu instansi yang dapat menyalurkan bantuan kepada masyarakat secara langsung. Pemerintahan merupakan semua persoalan kenegaraan yang bertujuan untuk menyelenggarakan kesejahteraan rakyat serta terkait urusan kepentingan kenegaraan ${ }^{1}$. Sedangkan pengertian pemerintah dalam arti sempit adalah pemangku jabatan yang bertugas sebagai pelaksana kekuatan eksekutif ataupun penyelenggara dalam bidang administrasi negara ${ }^{2}$. Bantuan-bantuan tersebut digunakan untuk kemajuan masyarakat dan daerah yang mencakup instansi tersebut berada. Pemberian bantuan-bantuan tersebut dapat berupa bantuan sosial maupun dapat berupa hibah. ${ }^{3}$ Besar kecilnya pemberian bantuan sosial dan hibah tergantung pada setiap pendapatan di masing-masing daerah itu sendiri baik itu pada taraf kabupaten atau kota ataupun pada provinsi, pendapatan di setiap daerah sering disebut dengan Pendapatan Asli Daerah (PAD). Penyelenggaraan kegiatan pemerintah di daerah adalah merupakan suatu bentuk nyata dari pemerintahan di seluruh wilayah Indonesia. Setiap daerah memiliki otonomi tersendiri, otonomi daerah sendiri memberikan hak untuk mengelola keuangan daerah secara mandiri tetapi masih ada kaitannya dengan pemerintah pusat ${ }^{4}$. Bantuan sosial dapat diberikan dari pemerintah daerah (pemda) kepada masyarakat-masyarakat yang membutuhkan baik itu diberikan kepada setiap individu maupun kelompok yang ada di masyarakat. Pemberian bantuan hibah berasal dari pemerintah daerah yang diperuntukkan kepada pemerintah ataupun pemerintah daerah lainnya, badan-badan usaha yang dimiliki oleh setiap daerah, kelompok usaha yang ada pada masyarakat, dan juga organisasiorganisasi dalam masyarakat. Bantuan sosial sangat diharapkan oleh masyarakat banyak yang sangat memerlukan bantuan ${ }^{5}$. Bantuan sosial dan hibah tersebut tidak dapat diberikan secara terus menurus kepada penerima hibah yang sama. Hal ini dimaksudkan agar terciptanya penyelenggaraan terkait urusan ke pemerintahan agar merata yang sesuai dengan asas keadilan. Bantuan sosial serta hibah pada mulanya dilakukan dengan cara "gelondongan" yang ditujukan pada daerah tertentu dalam tahap perencanaan anggaran.

Dalam mengurus suatu bangsa yang besar seperti bangsa Indonesia, pemerintah pusat dan juga pemerintah daerah memiliki suatu kaitan antara satu dengan yang lainnya, hal ini tercantum pada Pembukaan UUD 1945 yakni dalam alenia ke tiga dan alenia ke empat. Alenia ke tiga mengatur tentang kemerdekaan bangsa Indonesia dan selanjutnya alenia keempat mengatur bahwa setelah menyatakan kemerdekaan bangsa

${ }^{1}$ Ridwan, HR., Hukum Administrasi Negara, (Jakarta, PT. RajagrafindoPersada, 2011), 30.

2 Abdullah, D., "Hubungan Pemerintah Pusat Dengan Pemerintah Daerah". Jurnal Hukum Positum 1, No. 1, (2016), 83-103.

3 Arna, G.A.E.S, "Kewenangan Pemerintah Provinsi Bali Dalam Pemberian Hibah Kepada Desa Pakraman". Jurnal Magister Hukum Udayana (Udayana Master Law Journal) 5, No. 3, (2016), 573-590.

4 Sumbu, T., "Hubungan Pemerintah Pusat Dengan Pemerintah Daerah Dalam Kerangka Pengelolaan Keuangan Negara Dan Daerah". Ius Quia Iustum Law Journal 4, No. 17, (2010), 567-588.

${ }^{5}$ Purnia, S.P, Syaifur, R, \& Achmad, "Pengembangan Implementasi Aplikasi Bantuan Sosial Berbasis Mobile Pada Dinas Sosial". Jurnal Komputer dan Teknik Informatika 4, No. 2, (2019), 162-170. 
Indonesia, yang pertama kali di bentuk adalah Negara Republik Indonesia ${ }^{6}$. Bersamaan dengan itu di bentuk juga pemerintahan yang bertanggung jawab secara langsung mengurus negeri ini.

Secara perdata, pengertian dari penghibahan ada pada Pasal 1666 ayat (1) KUHPdt, pengertian dari penghibahan merupakan suatu bentuk persetujuan atas penghibahan suatu barang secara tulus ikhlas dan cuma-cuma tanpa ada paksaan dari pihak manapun yang bertujuan untuk kepentingan dari penerima hibah itu sendiri. Pemberian hibah kepada masyarakat, tidak semata-mata dilakukan secara acak. Calon penerima hibah harus terlebih dahulu mengajukan suatu usulan berupa suatu proposal yang berisikan tujuan dari dana hibah tersebut, dan juga jumlah anggaran yang diminta. Pengaturan tentang hibah dan bantuan sosial sendiri ada dalam Peraturan Menteri Dalam Negeri Republik Indonesia Nomor 14 Tahun 2016 tentang Perubahan Kedua Atas Peraturan Menteri Dalam Negeri Republik Indonesia Nomor 32 Tahun 2011 Tentang Pedoman Pemberian Hibah dan Bantuan Sosial Yang Bersumber Dari Anggaran Pendapatan Dan Belanja Daerah (selanjutnya disebut Permendagri No. 14/2016). Dalam Pasal 1 ayat (14) Permendagri No. 14/2016, Hibah adalah pemberian dana/uang ataupun barang serta jasa yang diberikan dari pemerintah daerah kepada pemerintahan pusat, pemerintah daerah lainnya, BUMN/BUMD, badan, organisasi serta lembaga yang ada di masyarakat yang memiliki badan hukum Indonesia, yang secara jelas telah diatur dan diperuntukkan dalam suatu hal atau kegiatan, hibah sendiri bersifat tidak wajib serta tidak mengikat yang bertujuan untuk menyelenggarakan urusan pemerintah daerah.

Dalam rangka meningkatkan kemajuan daerah dan menangani masalah-masalah sosial yang ada pada masyarakat, pemerintah daerah menyisihkan Anggaran Pendapatan Dan Belanja Daerah (APBD) untuk belanja daerah guna pemberian bantuan sosial (bansos) dan hibah sebagaimana hal tersebut memang dianggarkan setiap tahunnya oleh pemerintah. Pengalokasian belanja hibah dan bantuan sosial ke dalam APBD kabupaten/kota di Indonesia adalah salah satu bentuk wujud nyata dalam membangun infrastruktur di daerah-daerah. Selain meningkatkan infrastruktur di suatu daerah, bansos dan hibah juga bertujuan untuk pembangunan sosial seperti pengentasan kemiskinan dan menjaga lingkungan.

Dalam meningkatkan infrastruktur daerah, pemerintah melakukan peningkatan terhadap alokasi dana hibah serta bansos. Hal ini tidak hanya terjadi pada tingkat nasional tapi juga terjadi pada tingkat daerah7. APBD merupakan acuan untuk mengelola keuangan daerah selama 1 (satu) tahun anggaran mulai dari tanggal 1 Januari sampai tanggal 31 Desember ${ }^{8}$. APBD digunakan untuk menentukan besar kecilnya suatu pendapatan, dapat juga digunakan untuk perencanaan infrastruktur pembangunan, dan alat otoritas pengeluaran jangka panjang. Bali adalah salah satu provinsi di Indonesia yang terkenal akan keindahan alam dan kultur budayanya. APBD Bali tergolong cukup tinggi di Indonesia. Oleh karena itu anggaran belanja

6 Sianturi, H., "Kedudukan Keuangan Daerah Dalam Pengelolaan Dana Hibah Dan Bantuan Sosial Berdasarkan Perspektif Keuangan Negara", Wawasan Yuridika 1, No. 1, (2017), 86-106, http://dx.doi.org/10.25072/jwy.v1i1.129.

7 Saragintan, A. \& Hidayat, S., "Politik Pork Barrel di Indonesia: Kasus Hibah dan Bantuan Sosial di Provinsi Banten Tahun 2011". Jurnal Politik 2, No. 1, (2016), 137-164, https://doi.org/10.7454/jp.v2i1.85.

8 Muin, F., "Otonomi Daerah Dalam Perspektif Pembagian Urusan PemerintahPemerintah Daerah Dan Keuangan Daerah". Fiat Justisia Jurnal Ilmu Hukum 8, No. 1, (2014), 1978-5186. 
daerah dapat digunakan untuk meningkatkan kemajuan infrastruktur yang ada di Bali. Selain digunakan untuk infrastruktur pembangunan, dana hibah dianggarkan setiap tahun oleh pemerintah Provinsi Bali untuk diberikan kepada kelompok masyarakat ${ }^{9}$. Karena apabila berbicara tentang khususnya Bali, hal ini tidak lepas budaya-budaya masyarakat hukum adat.

Kabupaten Badung merupakan salah satu kabupaten di Bali yang memiliki pendapatan daerah yang cukup besar, hal ini dapat dilihat dari pendapatan per tahunnya. Dalam meningkatkan dan membangun infrastruktur yang baik, pemerintah daerah memberikan bantuan sosial dan hibah kepada desa-desa maupun organisasi masyarakat agar nantinya untuk kemajuan seluruh desa yang ada di Kabupaten Badung. Dalam penggunaan dana hibah, Kabupaten Badung memberikan dana hibah tersebut kepada masyarakat yang ada di kabupaten tersebut. Peraturan yang mengatur tentang hibah di Kabupaten Badung adalah Peraturan Bupati Badung Nomor 43 Tahun 2018 Tentang Pedoman Pemberian Hibah (Perbup Badung No. 43/2018). Sumber dana hibah pemerintah daerah (pemda) bersumber dari Anggaran Pendapatan dan Belanja Daerah (APBD), dimulai dari penyampaian permohonan usulan pemohon, evaluasi dan rekomendasi Satuan Kerja Perangkat Daerah (SKPD) terkait, pertimbangan Tim Anggaran Pemerintah Daerah (TAPD), pencantuman KUA\&PPAS (Kebijakan Umum Anggaran dan Prioritas Anggaran Sementara), sampai dengan penganggaran dalam kelompok belanja. Hibah sendiri dapat diberikan dalam bentuk uang ataupun dalam bentuk barang dan jasa. Pemberian dana hibah harus mencantumkan daftar-daftar dari penerima hibah, alamat dari penerima serta jumlah bantuan yang akan diberikan oleh kepala daerah.

Tujuan daripada hibah sendiri adalah untuk memberikan bantuan kepada badan, lembaga maupun organisasi kemasyarakatan yang kurang mampu agar dapat memenuhi kebutuhan mereka. Selain itu, tujuan pemberian hibah sendiri untuk melaksanakan pembangunan yang merata agar terciptanya pembangunan yang berkembang dan berkelanjutan. Pengelolaan dana hibah diharuskan secara tertib, efektif dan efisien, transparan, ekonomis, bertanggungjawab serta sesuai dengan aturan yang berlaku.

Dalam perkembangannya, kelompok-kelompok masyarakat sudah dapat menerima bantuan dana hibah. seperti misalnya di Bali, organisasi masyarakat di seperti subak, sekaa truna, banjar, pura, desa pakraman dan lain-lain telah dapat mengajukan diri sebagai organisasi masyarakat yang dapat menerima hibah dengan syarat adanya suatu pengukuhan dan keterangan domisili dari instansi yang terkait.

Dana hibah yang telah diberikan kepada masyarakat harus dipertanggungjawabkan dan digunakan sesuai dengan usulan yang telah disepakati oleh pemberi hibah maupun penerima hibah. Pertanggungjawaban hibah diatur lebih lanjut oleh kepala daerah dan menetapkan batas akhir pertanggungjawaban hibah tersebut. Pertanggungjawaban ini dimaksudkan agar masyarakat tidak sewenang-wenang menggunakan dana hibah tersebut. Dalam Perbup Badung No. 43/2018, tidak ada aturan yang mengatur pertanggungjawaban kepada penerima hibah apabila dana hibah tersebut diperuntukkan untuk hal yang lain atau digunakan untuk maksud tertentu dan juga tidak adanya contoh sanksi dalam peraturan tersebut.

${ }^{9}$ Ira, D., "Pemberian Hibah Berdasarkan Peraturan Gubernur Bali Nomor 2 Tahun 2017

Tentang Pedoman Pemberian Hibah Dan Bantuan Sosial". Acta Comita Jurnal Hukum Kenotariatan 3, No. 2, (2018), 2502-8960. 


\subsection{Rumusan Masalah}

Rumusan masalah dalam penelitian ini adalah:

1. Bagaimana tanggung jawab penerima hibah dalam penggunaan dana hibah yang tidak sesuai dengan usulan penggunaan dana hibah?

2. Sanksi apa yang dapat dijatuhkan apabila penggunaan hibah tidak sesuai dengan usulan yang telah disetujui?

\subsection{Tujuan Penelitian}

Tujuan dalam penelitian ini untuk menjelaskan dan menyampaikan pemaparan terkait pengaturan tanggung jawab penerima hibah dalam penggunaan dana hibah serta mengetahui dan mengkaji secara terperinci mengenai sanksi yang dapat dijatuhkan apabila penggunaan dana hibah tersebut menyimpang dari usulan yang telah disahkan dan disetujui oleh kepala daerah.

\section{Metode Penelitian}

Penulisan penelitian ini menggunakan metode penelitian normatif yang mana meneliti aturan hukum atau tatanan norma terkait dengan adanya peristiwa hukum yang terjadi. Maksud dari penulisan penelitian ini adalah memberikan suatu argumentasi dalam hukum dan sebagai pertimbangan dalam suatu permasalahan hukum. Dengan jenis pendekatan yakni pendekatan perundang-undangan (statute approach), yang dilakukan dengan menelaah Permendagri No.14/2016 dan Perbup Badung No. 43/2018. Bahan hukum dalam studi ini adalah bahan hukum primer di dapat pada peraturan perundang-undangan, sedangkan bahan hukum sekunder berasal dari literatur (baik asing maupun tidak), penelitian terdahulu, jurnal-jurnal, dan lain sebagainya.

\section{Hasil dan Pembahasan}

\subsection{Tanggung Jawab Penerima Hibah}

Hibah daerah merupakan suatu perjanjian yang mana pemerintah sepakat untuk meberikan bantuan berupa dana maupun barang/jasa kepada organisasi kemasyarakatan. Supaya mendapatkan bantuan hibah, terlebih dahulu pemerintah harus mengajukan proposal dimana proposal tersebut berisikan nama organisasi, tujuan penggunaan dana hibah, rancangan anggaran belanja (RAB), serta identitas dari pengurus organisasi tersebut. Sebagaimana pada Pasal 1313 KUHPdt yang menyatakan bahwa perikatan tersebut merupakan persetujuan antara satu pihak dengan pihak yang lainnya, yang mana hal ini akan menimbulkan suatu hak dan kewajiban, serta apabila dilanggar akan mendapatkan sebuah sanksi.

Pasal 1320 KUHPdt mengatur sahnya suatu perikatan, yakni:

1. Kata sepakat;

2. Cakap akan hukum;

3. Adanya objek yang diatur;

4. Sesuai dengan peraturan hukum.

Dalam perjanjian terlebih dahulu adanya kata sepakat yang mana dalam perjanjian hibah tersebut kata sepakat tersebut ditunjukkan dengan diterbitkannya Surat Keputusan Bupati tentang nama kelompok masyarakat mana saja yang akan dibantu serta alamat dan peruntukannya. Cakap hukum berkaitan dengan subyek 
hukum itu sendiri. Cakap hukum sendiri menurut hukum perdata ada 4 kategori, yaitu: pertama adalah orang dapat dikatakan dewasa menurut hukum apabila mereka telah berusia 21 (dua puluh satu) tahun, kedua adalah orang tersebut telah menikah walaupun usianya belum genap 21 (dua puluh satu) tahun, ketiga adalah seseorang yang tidak berada di bawah pengampunan atau seseorang tersebut tidak sedang dalam menjalankan hukuman, keempat merupakan orang tersebut sehat secara jasmani dan rohani atau tidak dalam gangguan jiwa. Subyek dalam perjanjian hibah ini adalah bupati dan juga pengurus dari kelompok masyarakat (ketua, sekretaris, dan bendahara). Objek dalam hibah dan bansos ini adalah permohonan bantuan yang diperuntukkan kepada bupati yang berisikan tujuan dari pengajuan hibah tersebut seperti misalnya pengadaan sarana dan prasarana serta pembangunan tempat suci dan lain-lain. Permohonan perjanjian hibah ini tidak bertentangan dengan peraturan yang berlaku karena sudah diatur dalam Perbup Badung No. 43/2018 yang mana berisikan permohonan pemberian hibah daerah. Perjanjian hibah sendiri akan ditandatangani oleh kedua belah pihak melalui Naskah Perjanjian Hibah Daerah (NPHD). Syarat subjektif terdapat pada nomor satu dan dua yaitu terkait subjek hukum dalam perikatan. Jika syarat subjektif ini tidak sesuai, maka perikatan dapat dibatalkan. Syarat objektif terkait benda perjanjian terdapat pada nomor tiga dan empat, jika syarat tersebut tak sesuai, maka batal demi hukum.

Pemerintah daerah mempunyai kewenangan untuk membuat aturan sendiri yang mana harus berpedoman pada peraturan yang lebih tinggi. Dalam hukum administrasi publik, ada tiga cara untuk memperoleh kewenangan pemerintahan (bestuurbevoegheid), yakni: atribusi (suatu kewenangan yang bersumber dari pembagian kekuasaan oleh peraturan perundang-undangan kepada organ-organ pemerintahan), delegasi (penyerahan wewenang pemerintahan yang dimiliki oleh suatu organ pemerintahan kepada orang lain atau instansi lainnya), mandat (merupakan hubungan secara intern/internal oleh pejabat publik dalam pemerintahan). ${ }^{10}$ Dengan adanya kewenangan ini, pemda memberikan bantuan dana berupa hibah dan bansos kepada masyarakat dengan tahap-tahap yang telah ditentukan dalam peraturan bupati.

Dalam Pasal 2 Perbup Badung No.43/2018, dalam hal pemberian hibah terdapat asas yang harus diperhatikan yakni:
a. Asas Keadilan;
b. Asas Kepatutan;
c. Rasionalitas;
d. Transparansi;
e. Akuntabilitas; dan
f. Bermanfaat untuk rakyat banyak.

Dana hibah dapat diberikan kepada masyarakat baik itu berupa lembaga, badan maupun organisasi dalam masyarakat. Hal ini bertujuan untuk meningkatkan taraf hidup serta meningkatkan kesejahteraan masyarakat yang terdapat pada setiap daerah. Sebagai contoh adalah pemberian dana hibah di Kabupaten Badung, pemberian dana hibah untuk masyarakat Kabupaten Badung harus pengajuan proposal permohonan dana hibah kepada Bupati Badung. Sesuai dengan Pasal 26 Perbup Badung No. 43/2018, tanggungjawab pemda dalam memberikan dana hibah mencakup: a. pembuatan usulan kegiatan dana hibah dari penerima hibah kepada

10 Susilo, A.B., "Makna Dan Kriteria Diskresi Keputusan Dan/Atau Tindakan Pejabat Publik Dalam Mewujudkan Tata Pemerintahan Yang Baik". Jurnal Hukum dan Peradilan 4, No. 1, (2015), 133-152, http://dx.doi.org/10.25216/JHP.4.1.2015.133-152. 
bupati; b. dengan adanya usulan kegiatan tersebut, bupati membuat keputusan tentang penetapan daftar penerima hibah; c. Pemerintah membuat Naskah Perjanjian Hibah Daerah (NPHD); d. selain membuat NPHD, pemda juga harus membuat pakta integritas yang berisikan penggunaan dana hibah akan digunakan sesuai dengan proposal yang diajukan dan pakta integritas ini ditandatangani oleh penerima hibah; e. bukti penyerahan dan penerimaan barang dan jasa apabila hibah berupa barang dan jasa, serta bukti transfer apabila hibah berupa uang.

Dalam pembahasan ini menggunakan teori tanggung jawab hukum. Menurut Hans Kelsen yaitu setiap orang yang melanggar hukum, harus bertanggungjawab secara penuh atas perbuatan yang dilakukannya dan akan menerima konsekuensi apapun. ${ }^{11}$

Pertanggungjawaban tidak sepenuhnya dibebankan kepada pemerintah daerah saja akan tetapi dibebankan pula kepada penerima hibah. Penerima hibah harus bertanggungjawab dengan membuat laporan pertanggungjawaban (LPJ) yang berisikan laporan keuangan yang digunakan dan laporan tersebut harus sesuai dengan usulan kegiatan yang diajukan. Dalam LPJ juga harus dimuat hasil (foto) dari peruntukan dana hibah tersebut, dalam hal ini lebih pada bentuk fisik seperti pembangunan dan pengadaan barang/jasa. LPJ dalam bentuk uang harus disampaikan kepada Pejabat Pengelola Keuangan Daerah dengan tembusan kepada unit kerja atau SKPD terkait. Untuk penerimaan hibah dalam bentuk barang dan/atau jasa, penyampaian LPJ diajukan kepada bupati melalui kepala SKPD terkait.

Penerima hibah memiliki tanggungjawab penuh baik secara formal maupun material terkait dengan penggunaan dana hibah yang telah diterimanya. Pelaporan pertanggung jawaban berisikan laporan penggunaan hibah, surat pernyataan pertanggungjawaban atas dana hibah, bukti-bukti dalam menggunakan dana hibah yang sesuai dengan peraturan yang berlaku. Pelaporan pertanggungjawaban sendiri diserahkan kepada bupati paling lambat tanggal 10 Januari tahun anggaran berikutnya (Pasal 27 ayat (3) Perbup Badung No. 43/2018).

Dalam prosedur memberikan dana hibah harus sesuai dengan standar pelayanan dan aturan yang berlaku pada SKPD yang diberikan tugas dan wewenang untuk mengelola bantuan dana hibah. SKPD harus betul-betul memahami dan memberikan informasi yang selengkap-lengkapnya kepada organisasi masyarakat terkait dengan tata cara dan pedoman pemberian hibah. Agar nantinya kesadaran masyarakat atau penerima hibah menyerahkan laporan pertanggungjawaban keuangan optimal.

Pemberian bantuan dana hibah harus dioptimalkan oleh penerima hibah, karena apabila penerima hibah tidak menyerahkan laporan pertanggungjawaban dana hibah tersebut atau jumlah dana berbeda dengan laporan yang diberikan, maka hal tersebut akan menjadi suatu masalah bagi organisasi masyarakat atau penerima hibah sendiri dan memberikan dampak yang buruk kepada Pemerintah Daerah. Laporan pertanggungjawaban keuangan harus disampaikan kepada SKPD terkait agar nantinya tidak ada temuan oleh Badan Pemeriksa Keuangan (BPK).

Terkait dengan monitoring dan evaluasi terhadap penggunaan dana hibah dilakukan oleh SKPD atau Unit Kerja terkait dan hasil dari monitoring dan evaluasi tersebut disampaikan kepada Bupati. Apabila laporan pertanggungjawaban dana hibah yang disampaikan oleh masyarakat tidak sesuai dengan hasil monitoring oleh

${ }^{11}$ Kelsen, H., Teori Umum Tentang Hukum Negara, (Jakarta, PT. Raja Grafindo Persada, 2006), 81. 
SKPD terkait, maka masyarakat harus bertanggungjawab secara penuh atas dana yang digunakan dengan cara mengembalikan secara penuh dana tersebut kepada pemerintah. Dalam penggunaan dana hibah, apabila dana hibah tersebut masih tersisa maka dana tersebut harus dikembalikan kepada pemerintah.

\subsection{Sanksi}

Sanksi hukum merupakan suatu hukuman yang dijatuhkan kepada seseorang karena telah melakukan perbuatan yang melanggar hukum. Sanksi hukum ada tiga macam yaitu sanksi perdata, sanksi pidana, serta sanksi administrasi. Sanski perdata dapat berupa denda dan ganti rugi. Sanksi pidana merupakan sanski yang dijatuhkan kepada seseorang karena telah melanggar ketentuan hukum pidana. Sanksi pidana dapat berupa denda, kurungan, penjara, penyitaan, bahkan hukuman mati. Sanksi perdata merupakan sanksi yang dijatuhkan kepada seseorang karena telah melanggar aturan hukum yang dibuat dalam perjanjian/perikatan. Sanksi administrasi merupakan sanksi yang dijatuhkan oleh pemerintah terhadap seseorang maupun terhadap badan hukum seperti misalnya pencabutan ijin usaha, pembayaran pajak, dan lain sebagainya.

Laporan pertanggungjawaban yang telah diajukan kepada bupati melalui SKPD terkait akan diperiksa dan dikelola oleh Badan Pemeriksa Keuangan (BPK) melalui hasil monitoring dan evaluasi terhadap penggunaan dana hibah. Hal ini untuk memastikan apakah penggunaan dana hibah itu sudah sesuai dengan tujuan kegiatan yang telah diajukan sebelumnya. Apabila ada suatu temuan oleh BPK terkait dana hibah, maka penerima hibah akan panggil dan diperiksa serta dapat pula dijatuhkan sanksi dalam peraturan perundang-undangan.

Sebagai contoh, apabila penerima hibah menggelapkan dana hibah, maka yang bersangkutan dikenakan tindak pidana penggelapan. Sanksi yang dapat dijatuhkan terhadap kasus tersebut adalah Bab XXIV tentang Penggelapan seperti pada pasal 372 Kitab Undang-Undang Hukum Pidana yakni "suatu perbuatan yang dilakukan seseorang atau lebih yang dengan sengaja melakukan perbuatan yang bertentangan dengan hukum serta memiliki barang baik itu sebagian ataupun keseluruhan yang dimiliki oleh orang lain dengan tujuan untuk menguasai atau digunakan untuk tujuan yang lain diancam karena penggelapan, serta sanksi yang dapat dijatuhkan yakni pidana penjara maksimal empat tahun ataupun dijatuhkan denda maksimal sebesar sembilan ratus rupiah".

Bilamana penggunaan dana hibah tidak sesuai dan berbeda dengan usulan kegiatan yang sudah disetujui atau penerima bantuan hibah telah menerima dana hibah secara berturut-turut, maka penerima hibah dikenakan sanksi administratif berupa pengembalian dana hibah tersebut kepada pemerintah daerah secara penuh.

\section{Kesimpulan}

Dalam hal pertanggungjawaban penerima hibah terdapat dalam Pasal 27 ayat (2) Peraturan Bupati Badung Nomor 43 Tahun 2018 Tentang Pedoman Pemberian Hibah yang mana tanggung jawab penerima hibah mencakup: laporan penggunaan hibah, pembuatan surat pertanyaan pertanggungjawaban atas dana hibah yang telah diterima dan pembuatan bukti penggunaan dana hibah secara lengkap sesuai dengan peraturan yang berlaku. Dalam laporan pertanggungjawaban dana hibah yang disampaikan oleh masyarakat tidak sesuai dengan hasil monitoring oleh SKPD terkait, maka masyarakat harus bertanggung jawab secara penuh atas dana yang digunakan dengan cara mengembalikan secara penuh dana tersebut kepada pemerintah. Dalam penggunaan 
dana hibah, apabila dana hibah tersebut masih tersisa maka dana tersebut harus dikembalikan kepada pemerintah. Sanksi yang dapat dikenakan penerima hibah apabila menyalahgunakan dana hibah dapat berupa sanksi administratif berupa pengembalian dana secara penuh kepada pemerintah daerah dan apabila penggunaan dana hibah tidak sesuai dan berbeda dengan usulan kegiatan yang sudah disetujui dan apabila penerima hibah menggelapkan dana hibah tersebut, dapat diberikan sanksi pidana sesuai dengan ketentuan dalam KUHP yaitu tindak pidana penggelapan dan harus mengembalikan dana hibah yang telah didapat.

\section{Daftar Pustaka \\ Buku}

Kelsen, H., Teori Umum Tentang Hukum Negara, (Jakarta, PT. Raja Grafindo Persada, 2006).

Ridwan, HR., Hukum Administrasi Negara, (Jakarta, PT. Rajagrafindo Persada, 2011).

\section{Jurnal}

Abdullah, D., "Hubungan Pemerintah Pusat Dengan Pemerintah Daerah". Jurnal Hukum Positum 1, No. 1, (2016), 83-103.

Arna, G.A.E.S., “Kewenangan Pemerintah Provinsi Bali Dalam Pemberian Hibah Kepada Desa Pakraman". Jurnal Magister Hukum Udayana (Udayana Master Law Journal) 5, No. 3, (2016), 573-590.

Ira, D., "Pemberian Hibah Berdasarkan Peraturan Gubernur Bali Nomor 2 Tahun 2017 Tentang Pedoman Pemberian Hibah Dan Bantuan Sosial". Acta Comita Jurnal Hukum Kenotariatan 3, No. 2, (2018), 2502-8960.

Muin, F., "Otonomi Daerah Dalam Perspektif Pembagian Urusan PemerintahPemerintah Daerah Dan Keuangan Daerah". Fiat Justisia Jurnal Ilmu Hukum 8, No. 1, (2014), 1978-5186.

Purnia, S.P., Syaifur, R., \& Achmad, R., "Pengembangan Implementasi Aplikasi Bantuan Sosial Berbasis Mobile Pada Dinas Sosial". Jurnal Komputer dan Teknik Informatika 4, No. 2, (2019), 162-170.

Saragintan, A. \& Hidayat, S., "Politik Pork Barrel di Indonesia: Kasus Hibah dan Bantuan Sosial di Provinsi Banten Tahun 2011". Jurnal Politik 2, No. 1, (2016), 137-164, https://doi.org/10.7454/jp.v2i1.85.

Sianturi, H., "Kedudukan Keuangan Daerah Dalam Pengelolaan Dana Hibah Dan Bantuan Sosial Berdasarkan Perspektif Keuangan Negara", Wawasan Yuridika 1, No. 1, (2017), 86-106, http://dx.doi.org/10.25072/jwy.v1i1.129.

Sumbu, T., "Hubungan Pemerintah Pusat Dengan Pemerintah Daerah Dalam Kerangka Pengelolaan Keuangan Negara Dan Daerah". Ius Quia Iustum Law Journal 4, No. 17, (2010), 567-588.

Susilo, A.B., "Makna Dan Kriteria Diskresi Keputusan Dan/Atau Tindakan Pejabat Publik Dalam Mewujudkan Tata Pemerintahan Yang Baik". Jurnal Hukum dan Peradilan 4, No. 1, (2015), 133-135, http://dx.doi.org/10.25216/JHP.4.1.2015.133-152.

\section{Peraturan Perundang-Undangan}

Undang-Undang Dasar Negara Republik Indonesia Tahun 1945.

Kitab Undang-Undang Hukum Perdata terjemahan Soedharyo Soimin, 2001.

Peraturan Menteri Dalam Negeri Republik Indonesia Nomor 14 Tahun 2016 tentang Perubahan Kedua Atas Peraturan Menteri Dalam Negeri Republik Indonesia 
Nomor 32 Tahun 2011 Tentang Pedoman Pemberian Hibah dan Bantuan Sosial Yang Bersumber Dari Anggaran Pendapatan Dan Belanja Daerah.

Peraturan Bupati Badung Nomor 43 Tahun 2018 Tentang Pedoman Pemberian Hibah. 